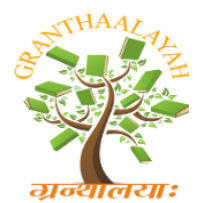

\author{
INTERNATIONAL JOURNAL OF RESEARCH - \\ GRANTHAALAYAH \\ A knowledge Repository
}

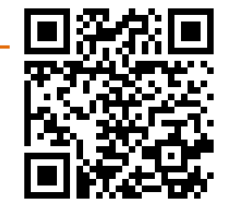

Science

\title{
YIELD MAXIMIZATION OF SWEET POTATOES (Ipomoea batatas [L.] Lam) WHITE VS RED CULTIVARS IN YOLA, ADAMAWA STATE OF NIGERIA
}

\author{
Toungos M.D ${ }^{1}$, Kwaga Y.D ${ }^{2}$, Zambua B.W ${ }^{3}$ \\ ${ }^{1}$ Crop Science Department, Adamawa State University Mubi, Adamawa State of Nigeria
}

\begin{abstract}
A Field experiment was conducted during the 2018 cropping season, at the Teaching and Research Farm of the Department of Agriculture Federal College of Education, (FCE) Yola. Yola is located in Northern Guinea Savanna Zone at latitude $9^{\circ} 14^{\prime}$ North and longitude $12^{\circ} 38^{\prime}$ East and altitude of $158 \mathrm{~m}$ above sea level. The treatments for experiment consist of two potato cultivars (White and Red) which vines were obtained from the open market in Yola and slips prepared from previous year's tubers. Complete Randomized Block Design (CRBD) was used and the treatments were replicated three (3) times. Both sweet and white potatoes provide similar amounts of key nutrients including protein ( $2 \mathrm{~g}$ and $3 \mathrm{~g}$ respectively), potassium and vitamin $\mathrm{B} 6$, all of which contribute to a well-balanced, nutrient-dense diet. It has 20.1g CHO, Starch 20.1g, Sugars 4.2g, Dietary fiber $3 g$, Protein $1.6 \mathrm{~g}$ and fat $0.1 \mathrm{~g}$. Soups, leaves and shoots are edible, Tubers roasted in many African Countries such as Kenya, South Sudan, Liberia, Guinea and Nigeria.their increased cultivation is being encouraged in Africa where vitamin A deficiency is a serious health problem. he highest yield of 8 tones $/ \mathrm{ha}^{-1}$ was recorded on the red cut vines, followed by 6 tones $/ \mathrm{ha}^{-1}$ on the white cut vines. There were no significant difference on the spread/uncut vines which gave yields of 3.6 tones $/ \mathrm{ha}^{-1}$ and 4.8 tones $/ \mathrm{ha}^{-1}$ while significant difference were observed on the cut vines with a mean weight tuber of 6.5 and 8.1 respectively. Results in sweet potato showed that, it has a good potential to the farmers in terms of yield and income. Their increased cultivation is being encouraged in Africa where vitamin A deficiency is a serious health problem. Their differences in terms of yield between the white and the red cultivars might be due to the methods adopted for planting the vines. It is therefore recommended to cut the vines when planting in order to obtain higher yield since yield is an important factor to be considered for sweet potato production.
\end{abstract}

Keywords: Sweet Potato; Cultivars; Yield.

Cite This Article: Toungos M.D, Kwaga Y.D, and Zambua B.W. (2019). "YIELD MAXIMIZATION OF SWEET POTATOES (IPOMOEA BATATAS [L.] LAM) WHITE VS RED CULTIVARS IN YOLA, ADAMAWA STATE OF NIGERIA." International Journal of Research - Granthaalayah, 7(8), 250-257. 10.29121/granthaalayah.v7.i8.2019.666. 


\section{Introduction}

Sweet potato is one of the world's most important food crops in terms of human consumption, particularly in Sub-Saharan Africa, parts of Asia, and the Pacific Islands. Ipomoea batatas, commonly called sweet potato or sweet potato vine, is native to tropical America. It is a tuberous rooted tender perennial that has been cultivated for its orange-fleshed edible tubers for over 2000 years. It was reportedly brought back to Europe from the New World by Columbus. It is now among the World's most important versatile and underutilized crop food crop grown generally for its storage roots as reported by Tortoe 2010. The crop is cultivated in more than 100 Countries as reported by Woolfe, 1992. But now it is found grown in many developing countries, more especially in Senegal and Nigeria than any other root crop. It is locally called Dankali, in Northern Nigeria and used as a stable diet for many family.

The sweet potato, or more scientifically, Ipomoea batatas, is a herbaceous perennial vine that has white and purple flowers, large nutritious storage roots and heart-shaped lobed leaves.

Sweet potato grows in marginal conditions, requiring little labor and chemical fertilizers. It is a cheap, nutritious solution for developing countries needing to grow more food on less area for rapidly multiplying populations. It also provides inexpensive, high-protein fodder for animals.

Morphology: The plant is a herbaceous perennial vine, bearing alternate heart-shaped or palmately lobed leaves and medium-sized sympetalous flowers. The edible tuberous root is long and tapered, with a smooth skin whose color ranges between yellow, orange, red, brown, purple, and beige. Its flesh ranges from beige through white, red, pink, violet, yellow, orange, and purple. Sweet potato cultivars with white or pale yellow flesh are less sweet and moist than those with red, pink or orange flesh as opined by Gad Loebenstein and George Thottappilly (2009).

The plant does not tolerate frost. It grows best at an average temperature of $24{ }^{\circ} \mathrm{C}$, abundant sunshine and warm nights. Annual rainfalls of 750-1,000 mm are considered most suitable, with a minimum of $500 \mathrm{~mm}$ in the growing season. The crop is sensitive to drought at the tuber initiation stage 50-60 days after planting, and it is not tolerant to water-logging, as it may cause tuber rots and reduce growth of storage roots if aeration is poor as reported by Ahn. Peter (1993).

Depending on the cultivar and conditions, tuberous roots mature in two to nine months.

With care, early-maturing cultivars can be grown as an annual crop. Sweet potatoes rarely flower when the daylight is longer than 11 hours. They are mostly propagated by stem or root cuttings or by adventitious shoots called "slips" that grow out from the tuberous roots during storage.

Sweet potatoes are grown on a variety of soils, but well-drained, light- and medium-textured soils with a pH range of 4.5-7.0 are more favorable for the plant. Woolfe, J.A. and Jennifer A. (1992). They can be grown in poor soils with little fertilizer. However, sweet potatoes are very sensitive to aluminum toxicity and will die about six weeks after planting if lime is not applied at planting in this type of soil as observed by Woolfe, J.A. and Jennifer A. (1992). Because they are sown by vine cuttings rather than seeds, sweet potatoes are relatively easy to plant. Because the rapidly growing vines shade out weeds, little weeding is needed. 
In 2016, global production of sweet potatoes was 105 million tones, led by China with $67 \%$ of the world total. In the same year 2016, the world average annual yield for sweet potato crop was 13 tones per hectare. The most productive yield of sweet potatoes was in Senegal, where the nationwide average annual yield was 39 tones per hectare as reported by "Sweet potato production in 2016". Production in the South Eastern Nigeria was recorded as 3.5 - 7 tones as reported by Ebulike et at 2001.

\section{Nutritional Value of Raw Sweet Potato Per 100g.}

Both sweet and white potatoes provide similar amounts of key nutrients including protein ( $2 \mathrm{~g}$ and $3 \mathrm{~g}$ respectively), potassium and vitamin B6, all of which contribute to a well-balanced, nutrientdense diet. It has 20.1g CHO, Starch 20.1g, Sugars 4.2g, Dietary fiber $3 \mathrm{~g}$, Protein $1.6 \mathrm{~g}$ and fat $0.1 \mathrm{~g}$.

Uses: soups, leaves and shoots are edible vegetables, good source of fodder for cattle, is also a good combination with rice in Nigeria. Tubers roasted in many African Countries such as Kenya, South Sudan, Liberia, Guinea and Nigeria.

\section{Materials and Methods}

\section{Experimental Sites}

A Field experiment was conducted during the 2018 cropping season, at the Teaching and Research Farm of the Department of Agriculture Federal College of Education, (FCE) Yola. Yola is located in Northern Guinea Savanna Zone at latitude $9^{\circ} 14^{\prime}$ 'North and longitude $12^{\circ} 38^{\prime}$ 'East and altitude of $158 \mathrm{~m}$ above sea level (Kowal and Knabe, 1972). Yola has an annual average minimum and maximum temperatures of $20.2^{\circ} \mathrm{C}$ and $43.5^{\circ} \mathrm{C}$. respectively (AD, ADP, 2001). Maximum rainfall in Yola is around August $\left(2,92.8 \mathrm{~mm} / \mathrm{mouth}^{-1}\right)$. The textural class of soils in the two sites is clay loam.

\section{Land Preparation}

The field was ploughed with tractor using disc plough. Hand hoe was used to further clear the remaining weeds and debris and ridges of $2 \mathrm{~m}$ long were made for the potato vines.

\section{Treatments and Experimental Design}

The treatments for experiment consist of two potato cultivars (White and Red) which vines were obtained from the open market in Yola and slips prepared from previous year's tubers. Complete Randomized Block Design (CRBD) was used and the treatments were replicated three (3) times.

\section{Agronomic Practices}

After ploughing and Making ridges of the experimental area, the field was marked out according to the design. Potato were planted using uncut vines and cut vines of $15 \mathrm{~cm}$ length of both potatoes on the ridges of 2 metres in an area $17 \mathrm{~m} \times 7 \mathrm{~m}$ given a total area of $119 \mathrm{~m} 2$. The vines were planted on $15^{\text {th }}$ June, 2018

\section{Data Collected on Agronomic Practices on Sweet Potato}

Data were collected on the following Characters in both cultivars and methods of planting. 


\section{Tuber length weeks after planting (WAP)}

The tube length of five tubers from the quadrat of the two cultivars were used for the measurement using $30 \mathrm{~cm}$ ruler at 4,8 and $10 \mathrm{WAP}$. The mean of the five tubers was calculated and recorded as tuber mean length $(\mathrm{cm})$.

\section{Diameter of the tubers weeks after planting (WAP)}

Five (5) tubers, from the two middle rows of both the White and the Red varieties were randomly selected and measured using veneer caliper and twine at 4, 8 and 10WAP, the average number of their diameters were used as the number of diameter per tuber at 4 weeks after planting.

\section{Weight of 5 tuber}

The weight of 5 randomly selected tuber from each ridge was determined using Triple Beam Balance 700/800 series by Ohans.

\section{Tuber Yield Per Ridge}

Tuber yield per ridge was recorded on both cultivars in order to get grain yield per ridge.

\section{Tuber Yield Per Hectare}

Tuber yield per hectare for each ridge/plot was computed as follows

$$
\frac{\text { Grain yield per ridge } / \text { plot }(\mathrm{kg})}{\text { Net plot size }(\mathrm{m} 2)} \quad \times 10,000 \mathrm{~m}^{2}
$$

\section{Statistical Analysis}

Data collected were analyzed statistically using the generalized linear mode (GLM) procedure of SAS (statistical analysis system v6. 12, 1994). Means that were statistically different were separated using least significant difference (LSD) at $\mathrm{p}<0.05$.

There were no significant difference $\mathrm{P}=0.05$ on mean length of potato tubers at $4 \mathrm{WAP}$ on both the white and red cultivars. The trend also applies to the uncut vines and the cut vines in all the cultivars as can be seen in Table 1 . The longest mean tuber length was $5.9 \mathrm{~cm}$ recorded from the red cultivar uncut vines while $5.8 \mathrm{~cm}$ was recorded in the white cultivar uncut vines. The uncut vines produced longer tuber length than the cut vines on both cultivars as can be seen on the table.

Table 1: Mean length of tubers $(\mathrm{cm})$

\begin{tabular}{|l|c|c|c|c|c|c|}
\hline & \multicolumn{5}{|c|}{ 4WAP } \\
\cline { 2 - 7 } & \multicolumn{3}{|c|}{ White cultivar } & \multicolumn{3}{c|}{ Red cultivar } \\
\cline { 2 - 7 } & $4.0 \mathrm{a}$ & $5.4 \mathrm{a}$ & $5.7 \mathrm{a}$ & $4.3 \mathrm{a}$ & $5.5 \mathrm{a}$ & $5.8 \mathrm{a}$ \\
\hline \multirow{3}{*}{ R1 Uncut vs cut vines. } & $3.8 \mathrm{a}$ & $5.4 \mathrm{a}$ & $5.6 \mathrm{a}$ & $4.2 \mathrm{a}$ & $5.4 \mathrm{a}$ & $5.7 \mathrm{a}$ \\
\hline & $3.8 \mathrm{a}$ & $5.2 \mathrm{a}$ & $5.5 \mathrm{a}$ & $4.6 \mathrm{a}$ & $4.8 \mathrm{a}$ & $5.9 \mathrm{a}$ \\
\cline { 2 - 7 } R2 Uncut vs cut vines. & $3.6 \mathrm{a}$ & $5.3 \mathrm{a}$ & $5.4 \mathrm{a}$ & $4.5 \mathrm{a}$ & $4.7 \mathrm{a}$ & $5.8 \mathrm{a}$ \\
\hline & $4.4 \mathrm{a}$ & $5.8 \mathrm{a}$ & $5.7 \mathrm{a}$ & $4.6 \mathrm{a}$ & $4.6 \mathrm{a}$ & $4.7 \mathrm{a}$ \\
\cline { 2 - 7 } R3 Uncut vs cut vines. & $4.4 \mathrm{a}$ & $5.7 \mathrm{a}$ & $5.8 \mathrm{a}$ & $4.5 \mathrm{a}$ & $4.5 \mathrm{a}$ & $4.6 \mathrm{a}$ \\
\hline Levels of significance & $\mathrm{Ns}$ & $\mathrm{Ns}$ & $\mathrm{Ns}$ & $\mathrm{Ns}$ & $\mathrm{Ns}$ & $\mathrm{Ns}$ \\
\hline
\end{tabular}

Source: Field work, 2018

Means followed by the same letter(s) in each treatment are not significantly different at $\mathrm{P}=0.05$ (DMRT). $*=$ Significantly different at $5 \%$ level of probability.

Ns $=$ Not significant at $5 \%$ level of probability. 
There was no significant difference at $\mathrm{P}=0.05$ at $8 \mathrm{WAP}$ in the uncut vines and the cut vines in all the treatments but significant difference were observed in tuber length at $8 \mathrm{WAP}$ between the cut vines and the uncut ones. The uncut vines had the longest mean tuber length than the cut ones. This indicates that the spread vines had longer tuber length as against the cut ones which were restricted on tuber length due to the length of the planting material as presented in Table 2 . The trends of tuber length also followed the pattern on Table 1, as can be seen on Table 2 .

Table 2: Mean length of tubers $(\mathrm{cm})$

Source: Field work, 2018

\begin{tabular}{|l|c|c|c|c|c|c|}
\hline & \multicolumn{6}{|c|}{ 8WAP } \\
\cline { 2 - 7 } & \multicolumn{4}{|c|}{ White cultivar } & \multicolumn{3}{c|}{ Red cultivar } \\
\hline \multirow{2}{*}{ R1 Uncut vs cut vines. } & $17.4 \mathrm{~b}$ & $18.6 \mathrm{a}$ & $18.9 \mathrm{a}$ & $18.5 \mathrm{~b}$ & $18.2 \mathrm{a}$ & $17.4 \mathrm{a}$ \\
\cline { 2 - 7 } & $17.3 \mathrm{~b}$ & $18.00 \mathrm{a}$ & $17.8 \mathrm{a}$ & $18.6 \mathrm{~b}$ & $17.6 \mathrm{a}$ & $18.4 \mathrm{a}$ \\
\hline R2 Uncut vs cut vines. & $18.2 \mathrm{~b}$ & $17.8 \mathrm{a}$ & $16.9 \mathrm{a}$ & $16.4 \mathrm{a}$ & $17.9 \mathrm{a}$ & $18.7 \mathrm{a}$ \\
\cline { 2 - 7 } & $18.2 \mathrm{~b}$ & $17.3 \mathrm{a}$ & $16.0 \mathrm{a}$ & $15.5 \mathrm{a}$ & $17.2 \mathrm{a}$ & $18.5 \mathrm{a}$ \\
\hline R3 Uncut vs cut vines. & $16.7 \mathrm{a}$ & $18.9 \mathrm{a}$ & $19.2 \mathrm{~b}$ & $18.6 \mathrm{~b}$ & $18.9 \mathrm{a}$ & $17.7 \mathrm{a}$ \\
\cline { 2 - 7 } & $16.3 \mathrm{a}$ & $17.2 \mathrm{a}$ & $18.3 \mathrm{a}$ & $15.7 \mathrm{a}$ & $17.4 \mathrm{a}$ & $16.5 \mathrm{a}$ \\
\hline Levels of significance & $*$ & $\mathrm{Ns}$ & $*$ & $*$ & Ns & Ns \\
\hline
\end{tabular}

Means followed by the same letter(s) in each treatment are not significantly different at $\mathrm{P}=0.05$ (DMRT). $*=$ Significantly different at $5 \%$ level of probability.

Ns $=$ Not significant at $5 \%$ level of probability.

At 10WAP Significant difference $P=0.05$ were observed between the cut vines and the uncut vines in the two cultivars in terms of mean tuber length as presented in Table 3 . The uncut vines had the longest tuber length as against the cut ones. The cut vines seems to produce larger tuber length. This is a determinant to higher yield as yield is an important factor in determining the type of planting method to use in potato. This agrees with the work of Njoku et al 2009 in their work in determining the yield of sweet potato genotypes. The longest mean length of tubers were recorded from the uncut vines of the red cultivar followed by the uncut vines of the white cultivar. There were no significant difference in term of cut vines in both cultivars.

Table 3: Mean length of tubers $(\mathrm{cm})$

\begin{tabular}{|l|c|c|c|c|c|c|}
\hline & \multicolumn{6}{|c|}{ 10WAP } \\
\cline { 2 - 7 } & \multicolumn{3}{|c|}{ White cultivar } & \multicolumn{3}{c|}{ Red cultivar } \\
\hline R1 Uncut and cut vines. & $13.2 \mathrm{a}$ & $26.6 \mathrm{~b}$ & $20.5 \mathrm{~b}$ & $18.8 \mathrm{a}$ & $21.4 \mathrm{ab}$ & $25.6 \mathrm{a}$ \\
\cline { 2 - 7 } & $16.5 \mathrm{~b}$ & $17.4 \mathrm{a}$ & $16.5 \mathrm{a}$ & $17.4 \mathrm{a}$ & $20.2 \mathrm{a}$ & $22.5 \mathrm{a}$ \\
\hline \multirow{2}{*}{ R2 Uncut vs cut vines. } & $23.7 \mathrm{c}$ & $24.5 \mathrm{~b}$ & $25.3 \mathrm{~b}$ & $26.8 \mathrm{~b}$ & $20.6 \mathrm{a}$ & $22.5 \mathrm{a}$ \\
\cline { 2 - 8 } & $20.4 \mathrm{c}$ & $22.5 \mathrm{~b}$ & $23.5 \mathrm{~b}$ & $24.4 \mathrm{~b}$ & $20.3 \mathrm{a}$ & $21.5 \mathrm{a}$ \\
\hline R3 Uncut vs cut vines. & $18.8 \mathrm{~b}$ & $22.4 \mathrm{~b}$ & $20,6 \mathrm{~b}$ & $24.7 \mathrm{~b}$ & $19.6 \mathrm{a}$ & $27 \mathrm{a}$ \\
\cline { 2 - 7 } & $18.3 \mathrm{~b}$ & $21.4 \mathrm{~b}$ & $20.2 \mathrm{~b}$ & $20.5 \mathrm{~b}$ & $18.5 \mathrm{a}$ & $25.1 \mathrm{a}$ \\
\hline Levels of significance & $*$ & $*$ & $*$ & $*$ & $*$ & Ns \\
\hline
\end{tabular}

Source: Field work, 2018

Means followed by the same letter(s) in each treatment are not significantly different at $\mathrm{P}=0.05$ (DMRT).

$*=$ Significantly different at $5 \%$ level of probability.

Ns $=$ Not significant at $5 \%$ level of probability. 
There was no significant difference at $\mathrm{P}=0.05$ in terms of root diameter at $4 \mathrm{WAP}$ in the two cultivars, the red and the white as presented in Table 4. However, slight differences were observed even though not statistically significant.

Table 4: Mean diameter of tubers $(\mathrm{cm})$

\begin{tabular}{|l|c|c|c|c|c|c|}
\hline \multirow{2}{*}{ R1 Uncut and cut vines. } & \multicolumn{6}{|c|}{ 4WAP } \\
\cline { 2 - 8 } & $4.5 \mathrm{a}$ & $4.7 \mathrm{a}$ & $4.5 \mathrm{a}$ & $4.4 \mathrm{a}$ & $4.5 \mathrm{a}$ & $4.4 \mathrm{a}$ \\
\cline { 2 - 7 } & $4.6 \mathrm{a}$ & $4.8 \mathrm{a}$ & $4.7 \mathrm{a}$ & $4.5 \mathrm{a}$ & $4.6 \mathrm{a}$ & $4.8 \mathrm{a}$ \\
\hline \multirow{2}{*}{ R2 Uncut vs cut vines. } & $4.4 \mathrm{a}$ & $5.5 \mathrm{a}$ & $4.3 \mathrm{a}$ & $4.8 \mathrm{a}$ & $4.6 \mathrm{a}$ & $4.5 \mathrm{a}$ \\
\cline { 2 - 7 } & $5.4 \mathrm{a}$ & $6.5 \mathrm{a}$ & $4.5 \mathrm{a}$ & $5.4 \mathrm{a}$ & $5.3 \mathrm{a}$ & $5.5 \mathrm{a}$ \\
\hline \multirow{2}{*}{ R3 Uncut vs cut vines. } & $4.8 \mathrm{a}$ & $5.4 \mathrm{a}$ & $5.6 \mathrm{a}$ & $5.7 \mathrm{a}$ & $4.6 \mathrm{a}$ & $4.6 \mathrm{a}$ \\
\cline { 2 - 7 } & $5.3 \mathrm{a}$ & $5.5 \mathrm{a}$ & $5.2 \mathrm{a}$ & $5.5 \mathrm{a}$ & $5.8 \mathrm{a}$ & $6.1 \mathrm{a}$ \\
\hline Levels of significance & $\mathrm{Ns}$ & $\mathrm{Ns}$ & $\mathrm{Ns}$ & $\mathrm{Ns}$ & Ns & Ns \\
\hline
\end{tabular}

Source: Field work, 2018

Means followed by the same letter(s) in each treatment are not significantly different at $\mathrm{P}=0.05$ (DMRT). $*=$ Significantly different at $5 \%$ level of probability.

Ns $=$ Not significant at $5 \%$ level of probability.

The potato tuber girth increased significantly at $\mathrm{P}=0.05$ between the cut vines and the spread/uncut vines. The cut vines had the largest mean diameter of tuber. This might not be unrelated to the length of the planting material being only $30 \mathrm{~cm}$ which had less competition for nutrients and photosynthesized higher than the spread ones producing higher assimilates from source to sink. These contributed to the cut ones having larger tuber diameters than the uncut ones. These trends follows on all the treatments as presented in Table 5.

Table 5: Mean diameter of tubers $(\mathrm{cm})$

\begin{tabular}{|l|c|l|l|l|l|l|}
\hline & \multicolumn{6}{|c|}{ WWAP } \\
\cline { 2 - 8 } & \multicolumn{4}{|c|}{ White cultivar } & \multicolumn{3}{c|}{ Red cultivar } \\
\hline R1 Uncut and cut vines. & $13.5 \mathrm{a}$ & $13.7 \mathrm{a}$ & $14.5 \mathrm{ab}$ & $13.4 \mathrm{a}$ & $13.5 \mathrm{a}$ & $14.4 \mathrm{ab}$ \\
\cline { 2 - 8 } & $15.6 \mathrm{~b}$ & $14.8 \mathrm{ab}$ & $15.7 \mathrm{~b}$ & $13.5 \mathrm{a}$ & $14.6 \mathrm{ab}$ & $14.8 \mathrm{ab}$ \\
\hline \multirow{2}{*}{ R2 Uncut vs cut vines. } & $13.3 \mathrm{a}$ & $13.5 \mathrm{a}$ & $13.4 \mathrm{a}$ & $14.2 \mathrm{ab}$ & $13.6 \mathrm{a}$ & $13.5 \mathrm{a}$ \\
\cline { 2 - 8 } & $13.4 \mathrm{a}$ & $14.5 \mathrm{ab}$ & $14.5 \mathrm{ab}$ & $15.4 \mathrm{~b}$ & $15.3 \mathrm{~b}$ & $14.5 \mathrm{ab}$ \\
\hline \multirow{2}{*}{ R3 Uncut vs cut vines. } & $13.8 \mathrm{a}$ & $13.4 \mathrm{a}$ & $14,6 \mathrm{ab}$ & $13.7 \mathrm{a}$ & $13.6 \mathrm{a}$ & $13.6 \mathrm{a}$ \\
\cline { 2 - 7 } & $15.3 \mathrm{~b}$ & $15.5 \mathrm{~b}$ & $15.2 \mathrm{~b}$ & $15.5 \mathrm{~b}$ & $15.8 \mathrm{~b}$ & $14.1 \mathrm{ab}$ \\
\hline Levels of significance & $*$ & $*$ & $*$ & $*$ & $*$ & $*$ \\
\hline
\end{tabular}

Source: Field work, 2018

Means followed by the same letter(s) in each treatment are not significantly different at $\mathrm{P}=0.05$ (DMRT). $*=$ Significantly different at $5 \%$ level of probability.

Ns $=$ Not significant at $5 \%$ level of probability.

At 10WAP the trends of the results are similar to that of 8WAS but differs in the size of mean diameter of tuber. Significant difference was also recorded in terms of tuber diameter at $\mathrm{P}=0.05$ at 10WAP. The red cultivar also proves to be more productive in terms of tuber diameter than the white cultivar as it be seen in Table 6 . The significant difference in terms of length and stem size (diameter) during 10WAP might not be unrelated to the methods used in planting the two cultivars. 
Table 6: Mean diameter of tubers $(\mathrm{cm})$

\begin{tabular}{|c|c|c|c|c|c|c|}
\hline & \multicolumn{6}{|c|}{ 10WAP } \\
\hline & \multicolumn{3}{|c|}{ White cultivar } & \multicolumn{3}{|c|}{ Red cultivar } \\
\hline & $14.5 \mathrm{a}$ & $19.7 b$ & $19,5 b$ & $17.4 \mathrm{ab}$ & $18.5 b$ & $17.4 \mathrm{ab}$ \\
\hline R1 Uncut and cut vines. & $20.6 b$ & $30.8 \mathrm{c}$ & $23.7 b$ & $25.5 b$ & $20.6 b$ & $21.8 \mathrm{a}$ \\
\hline \multirow[t]{2}{*}{ R2 Uncut vs cut vines. } & $15.4 \mathrm{a}$ & $16.5 \mathrm{ab}$ & $14.3 \mathrm{a}$ & $15.8 \mathrm{a}$ & $15.6 \mathrm{a}$ & $15.5 \mathrm{a}$ \\
\hline & $24.4 \mathrm{~b}$ & $22.5 b$ & $20.5 b$ & $19.4 \mathrm{~b}$ & $21.3 b$ & $20.5 b$ \\
\hline \multirow[t]{2}{*}{ R3 Uncut vs cut vines. } & $14.8 \mathrm{a}$ & $15.4 \mathrm{a}$ & $16,6 a$ & $17.7 \mathrm{ab}$ & $16.6 \mathrm{a}$ & $15.6 \mathrm{a}$ \\
\hline & $22.3 b$ & $19.5 b$ & $20.2 b$ & $21.5 b$ & $22.8 b$ & $20.1 b$ \\
\hline \multicolumn{7}{|l|}{ SE \pm} \\
\hline Levels of significance & $*$ & $*$ & $*$ & $*$ & $*$ & $*$ \\
\hline
\end{tabular}

Source: Field work, 2018

Means followed by the same letter(s) in each treatment are not significantly different at $\mathrm{P}=0.05$ (DMRT). $*=$ Significantly different at $5 \%$ level of probability.

Ns $=$ Not significant at $5 \%$ level of probability.

The mean weight of tubers at 4WAP was not significant in all the cultivars and the methods used in planting as can be seen in Table 7 . This might not be unrelated to the early competition by all the cultivars for survival, food storage and light for photosynthesis. But there was slight difference in terms of tuber weight between the cultivar as can be seen in the table with the red cultivar having highest tuber weight than the white cultivar at 4WAP, though statistically not significant.

Table 7: Mean weight of tubers $(\mathrm{kg})$

\begin{tabular}{|l|l|l|l|l|l|l|}
\hline \multirow{2}{*}{ R1 Uncut and cut vines. } & \multicolumn{5}{|c|}{ WWAP } \\
\cline { 2 - 7 } & $3.60 \mathrm{a}$ & $5.66 \mathrm{a}$ & $4.17 \mathrm{a}$ & $7.15 \mathrm{a}$ & $8.16 \mathrm{a}$ & $7.15 \mathrm{a}$ \\
\cline { 2 - 7 } & $4.56 \mathrm{a}$ & $5.80 \mathrm{a}$ & $6.65 \mathrm{a}$ & $7.81 \mathrm{a}$ & $8.60 \mathrm{a}$ & $8.12 \mathrm{a}$ \\
\hline \multirow{2}{*}{ R2 Uncut vs cut vines. } & $5.0 \mathrm{a}$ & $5.21 \mathrm{a}$ & $5.11 \mathrm{a}$ & $7.15 \mathrm{a}$ & $6.34 \mathrm{a}$ & $7.67 \mathrm{a}$ \\
\cline { 2 - 7 } & $5.4 \mathrm{a}$ & $5.22 \mathrm{a}$ & $6.04 \mathrm{a}$ & $7.45 \mathrm{a}$ & $7.21 \mathrm{a}$ & $8.13 \mathrm{a}$ \\
\hline \multirow{2}{*}{ R3 Uncut vs cut vines. } & $5.02 \mathrm{a}$ & $4.11 \mathrm{a}$ & $5.15 \mathrm{a}$ & $7.68 \mathrm{a}$ & $6.50 \mathrm{a}$ & $7.12 \mathrm{a}$ \\
\cline { 2 - 7 } & $5.12 \mathrm{a}$ & $5.34 \mathrm{a}$ & $6.22 \mathrm{a}$ & $8.13 \mathrm{a}$ & $7.24 \mathrm{a}$ & $7.54 \mathrm{a}$ \\
\hline Levels of significance & $\mathrm{Ns}$ & Ns & Ns & Ns & Ns & Ns \\
\hline
\end{tabular}

Source: Field work, 2018

Means followed by the same letter(s) in each treatment are not significantly different at $\mathrm{P}=0.05$ (DMRT). $*=$ Significantly different at $5 \%$ level of probability.

Ns $=$ Not significant at $5 \%$ level of probability.

Yield. The highest yield of 8 tones $/ \mathrm{ha}^{-1}$ was recorded on the red cultivar cut vines, followed by 6 tones/ha ${ }^{-1}$ on the white cultivar cut vines. There was no significant difference on the spread/uncut vines which gave yields of 3.6 tones $/ \mathrm{ha}^{-1}$ and 4.8 tones $/ \mathrm{ha}^{-1}$ respectively, while significant difference was observed on the cut vines with a mean weight tuber of 6.5 and 8.1 respectively. This is in close agreement with the yield of 3.5 - 7 tones/ha ${ }^{-1}$ obtained by Ezulike et al 2001 in South Eastern Nigeria. Chinaka, 1983 also obtained a yield of 4tones/ha ${ }^{-1}$ during his trial while Horton, 1988 obtained 13 tones/ha ${ }^{-1}$. 


\section{Conclusion}

Results in sweet potato showed that, it has a good potential to the farmers. Their increased cultivation is being encouraged in Africa especially in Northern Nigeria where vitamin A deficiency is a serious health problem. Their differences in terms of yield between the white and the red cultivars might be due to the methods adopted for planting the vines. It is therefore recommended to cut the vines when planting sweet potato in order to obtain higher yield since yield is an important factor to be considered for sweet potato production.

\section{References}

[1] AD, ADP, (2001). Adamawa, Agricultural Development Programme Weather Station, Yola, Adamawa State Nigeria.

[2] Ahn. Peter (1993). Tropical soils and fertilizer use. Intermediate Tropical Agriculture Series. UK: Longman Scientific and Technical Ltd. ISBN 978-0-582-77507-7.

[3] Chinaka, C.C., (1983). Sweet Potato production. Extension Bulletin No: 7, AERLS, National Root Crop Research Institute (NRCRI) Umudike, Nigeria. Pp 7-8.

[4] Ezulike, T.O., Aioke, S.C and Odurukwe, S.O (2001). Integrated control of sweet potato weevil (Cylas pucnticollis, Boh) in South Eastern Nigeria. In; Akoroda, M.O and Ngeve J.M., (Compilers). Root crops in the 21st Century. Proceeding of the 7th Triennial symposium of the International Society of Tropical Root crops, African Branch, held at the Centre International des Conference, Cotonou, Benin, 11-17 October, 1009, Pp. 645-648.

[5] Gad Loebenstein; George Thottappilly (2009). The sweetpotato. pp. 391-425. ISBN 978-1-40209475-0. Retrieved 28th July, 2019.

[6] Horton, D. (1988). Underground Crops. Winrock International Institute for Agricultural Development Morrilton, USA, Pp 22-23.

[7] Njoku, J.C, Muoneke, C.O, Okocj=ha, P.I and Ekeleme, F (2009). Effect of propagule size and intra-row spacing on the growth and yield of sweet potato in the humid Agro-ecological zone. Nigerian Agricultural Journal, (40)1: 115-124

[8] "Sweet potato production in 2016". Statistics Division (FAOSTAT). World Regions / Production Quantity. Food and Agriculture Organization of the United Nations. 2017. Retrieved 25 April 2018.

[9] Torto, C. (2010). Microbial determination of white variety sweet potato (Ipomea batatas) under different storage structures. International Journal of Plant Biology, 1(1): 10-15.

[10] Woolfe, J.A and Jennifer A. (5 March 1992). Sweet Potato: An untapped food resource. Cambridge, UK: Cambridge University Press and the International Potato Center (CIP). ISBN 9780521402958. Retrieved 31st July, 2019.

[11] Woolfe, J.A (1992). Sweet potato: An untapped food resources. International potato centre (CIP), Peru/Cambridge University Press, Cambridge, Pp. 16-19.

\footnotetext{
*Corresponding author.

E-mail address: dahiru.toungos@gmail.com/toungosm@ adsu.edu.ng
} 